Research Article

\title{
Risk perception, burnout, and knowledge of chemotherapy nurses during the COVID-19 pandemic
}

\author{
COVID-19 salgını sırasında kemoterapi hemşirelerinin risk algısı, tükenmişliği ve bilgisi
}

\section{Lokman Koral $^{\mathrm{a}}$}

a Department of Medical Oncology, Faculty of Medicine, Canakkale Onsekiz Mart University, Canakkale, Turkey

\begin{abstract}
Introduction: Not every individual exposed to the same stressors will develop the same symptoms of burnout. We aimed to evaluate the risk perception and burnout of chemotherapy nurses working with patients having possibly low immune resistances and investigate the relationship with the COVID-19 knowledge of the participants.

Methods: We carried out a cross-sectional study in oncology nurses between May and June 2020. Using Delphi panels, instruments were developed on COVID-19-related burnout and risk perception. Of the 857 nurses registered to the Association of Oncology Nurses, 267 responded to an online survey, including 28 items on demographic features, burnout, risk perception, and COVID-19 knowledge.

Results: The mean age of the participants was $34.8 \pm 8.4$ (min. 20, max. 58) years. The mean risk perception scores were $17.34 \pm 3.00$ (min. 6 , max. 24 ) and burnout scores were $16.74 \pm 4.44$ (min. 2, max. 27), both above two-thirds of the maximum possible limits. Knowledge scores, on the other hand, were relatively high $(72.09 \pm 20.0 \%)$. COVID-19 knowledge scores showed a significant positive correlation with burnout scores ( $\mathrm{r}=0.499$, $\mathrm{p}<0.001)$ but a negative correlation with age $(\mathrm{r}=-0.153, \mathrm{p}=0.013)$. There was no significant correlation between burnout scores and risk perception or risk perception and age $(\mathrm{p}>0.05)$. Linear regression analysis showed that after adjusting for the possible confounders, the COVID-19 knowledge score was the only significant variable independently affecting burnout scores (Beta $=0.109,95 \%$ Confidence Interval (CI): 0.086-0.133, $p<0.001$ ). Conclusions: During the COVID-19 pandemic, chemotherapy nurses are under significant pressure concerning risk perception and burnout. Increasing the knowledge of the nurses by in-service training could raise their awareness and risk perception. However, precautions must be taken to prevent work-related exhaustion and support nurses experiencing burnout.
\end{abstract}

Keywords: COVID-19, Medical Oncology, Oncology Nursing, Occupational Exposure, risk factors, Occupational Burnout

\section{$\ddot{O} \mathbf{z}$}

Giriş: Aynı stresörlere maruz kalan her birey aynı tükenmişlik belirtilerini geliştirmeyebilir. Bu araştırmada immün dirençleri düşük olabilen hastalarla çalışan kemoterapi hemşirelerinin risk algısı ve tükenmişlik düzeylerini değerlendirmeyi ve bunların COVID-19 bilgileri ile ilişkisini araştırmayı amaçladık.

Yöntemler: Onkoloji hemşirelerinde Mayıs-Haziran 2020 tarihleri arasında kesitsel bir çalışma yaptık. Delphi panelleri kullanılarak, COVID-19 ile ilgili tükenmişlik ve risk algısı araçları geliştirildi. Onkoloji Hemşireleri Derneği'ne kayıtlı 857 hemşireden 267'si, demografik özellikler, tükenmişlik, risk algıSı ve COVID-19 bilgisi ile ilgili 28 maddeyi içeren çevrimiçi bir ankete yanıt verdi.

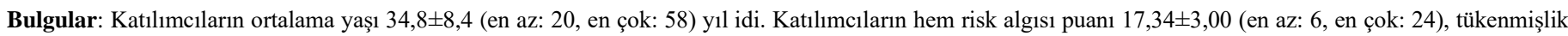

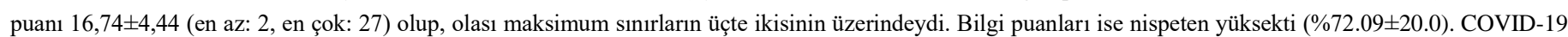
bilgi puanları tükenmişlik puanlarıyla pozitif $(\mathrm{r}=0,499, \mathrm{p}<0,001)$, yaşla negatif korelasyon $(\mathrm{r}=-0,153, \mathrm{p}=0,013)$ göstermekteydi. Tükenmişlik puanları ile risk algısı veya risk algısı ve yaş arasında anlamlı bir ilişki yoktu $(\mathrm{p}>0.05)$. Doğrusal bir regresyon analizi, olası karıştıııılar için düzeltme yapıldıktan sonra, tükenmişlik puanlarını bağımsız olarak etkileyen tek önemli değişkenin COVID-19 bilgi puanı olduğunu gösterdi (Beta=0.109, \%95 Güven Aralığı (GA): 0.086-0.133, p<0.001). Sonuç: Kemoterapi hemşireleri, COVID-19 salgını sürecinde risk algısı ve tükenmişlik açısından önemli bir baskı altındadır. Hizmet içi eğitimlerle hemşirelerin bilgi birikiminin artırılması, farkındalıklarını ve risk algılarını artırabilir. Bununla birlikte, işle ilgili yorgunluğu önlemeli ve tükenmişlik yaşayan hemşirelere destek olmak için önlemler alınmalıdır.

Anahtar kelimeler: COVID-19, Tıbbi Onkoloji, Onkoloji Hemşireliği, Mesleki Maruziyet, Risk faktörleri, Mesleki Tükenmişlik

\begin{tabular}{|c|c|c|c|c|}
\hline Received & Accepted & Published Online & Corresponding Author & E-mail \\
\hline November 30, 2020 & February 10, 2021 & August 30, 2021 & Lokman Koral, M.D. & lokmankoral@ @omu.edu.tr \\
\hline Correspondence & $\begin{array}{l}\text { Dr. Lokman Koral, ÇOMÜ Tıp Fakültesi Hastanesi Barbaros Mahallesi Prof. Dr. Sevim BULUÇ Sokak } \\
\text { Terzioğlu Yerleşkesi A Blok No:2 B Blok No:4, Çanakkale, Turkey }\end{array}$ \\
\hline
\end{tabular}




\section{Introduction}

The world is experiencing a new virus pandemic that threatens life. Because of its similarity to the previously isolated severe respiratory syndrome coronavirus SARS-CoV, the new virus is named SARS-CoV-2 [1]. Following neighboring countries such as Europe and Iran, the first cases of COVID-19 in Turkey were seen on 11 March 2020 [2]. Furthermore, healthcare professionals are at the forefront of the COVID-19 pandemic. Continuous exposure to infected patients and contaminated surfaces can put them at risk of contracting and transmitting infection [3].

Both the working conditions and the information disclosed during the process increased the anxiety and concerns of healthcare workers during the pandemic [4]. While the risks for the general public are relatively low, many infections have spread via unprotected healthcare workers, who come into direct contact with respiratory secretions of SARS patients. The majority of these healthcare workers were nurses [5]. Strong associations have been found between COVID-19 and advanced age, severe systemic disease, and cancer in terms of both transmission frequency and mortality [6]. Also, the transmission of the virus in the hospital environment is still a huge threat to healthcare professionals. Nurses are at the forefront of care and, therefore, more prone to infection [7].

Burnout has detrimental effects on nurses, patients, and healthcare organizations. A high prevalence of burnout and compassion fatigue was documented, especially in oncology nurses [12]. The concept of burnout was first described by Freudenberger in 1974. It refers to a long period of distress that leads to physical and emotional exhaustion with the reduction of body defenses as a result of the person's exposure to stress factors for a long time [8]. Nursing has been recognized as a risk profession for stress and burnout [9]. Although external stressors have a significant impact on the dimensions of burnout, not every individual exposed to the same stress situations will develop symptoms of burnout. Thus, it is essential to study the relationships between risk perception and burnout [10]. However, since the humans are afraid of the unknown [11], we hypothesized that knowledge could be a significant confounder in this equation.

\section{Objectives}

Most of the daily treatments of cancer patients are carried out in outpatient chemotherapy units. However, there is no previous data regarding the disease risk perceptions and burnout of oncology nurses in the widespread, deadly, and rapidly-progressing COVID-19 pandemic. In this study, we aimed to evaluate the risk perception and burnout of nurses working in outpatient units in close contact with a patient population having low immune resistance due to cancer and investigate the relationship with the COVID-19 knowledge of the participants.

\section{Methods}

\section{Study design and setting}

We carried out a cross-sectional study using specially designed self-administered questionnaires for oncology nurses, including the development and validation of the study instruments. Research reporting was done per the COSMIN checklist (COnsensus-based Standards for the selection of health status Measurement INstruments) [13].

\section{Instrument validation}

A panel of 6 experts (a specialist of oncology, a clinical microbiologist, two nurses, a specialist in Turkish, and a biostatistician) was generated to prepare the question pool. The collected questions were revised by the authors, including questions from a literature search. Using this method, we created items measuring COVID-19 knowledge, questions on self-perceived risk concerning COVID-19, and items assessing burnout. The researchers modified or removed duplicate items as well as problematic words and expressions that were not applicable in the context. Then, the initial panel of six experts was contacted to assess the suitability of each question by scoring them on a scale from 1 to 5 (1: the item is not appropriate, 5: the item is excellent). Questions with a high level of consensus were selected and compacted in a single final list, which contained 6 items on risk perception, 7 items on burnout, and 6 items regarding COVID-19 knowledge (Figure 1). Two of the risk perception items were reverse coded. Both the burnout and risk perception instruments used five-point Likert type responses (0: totally disagree, 1: disagree, 2: not sure, 3: agree, 4: totally agree). The knowledge scores were converted into a 100\% scale. Thus, the minimum and maximum risk perception, burnout, and knowledge scores were $0-24$ points, $0-28$ points, and $0-100 \%$, respectively. While higher risk perception and burnout scores meant worse status, higher knowledge scores indicated better COVID-19 knowledge.

\section{Pretesting}

The survey instrument, consisting of perceived risk $(n=6)$, burnout $(n=7)$, and knowledge $(n=6)$ questions, was applied to 10 randomly selected voluntary nurses from the study population to assess face validity. Qualitative opinions were taken to refine the survey items. Modification suggestions were noted. The process ended when all significant wording problems were detected and addressed. Participants could fill-in the questionnaire in $15-20$ minutes.

\section{Internal consistency and construct structure}

The internal consistency of the study instruments was determined using Cronbach's alpha. Test-retest reliability could not be conducted. The construct structure and subscales of the instruments were analyzed using exploratory factor analysis followed by the varimax rotation. The extraction method was based on Eigenvalues greater than 1. A minimum factor loading of 0.40 was used as the criterion for each retained item.

\section{Ethical approval}

Ethical approval for the study was obtained from the Çanakkale Onsekiz Mart University ethics committee (approval number: 07.05.2020 / 202007). Participants' responses were collected anonymously and kept confidential. A response to the online survey was accepted as the provision of informed consent. 


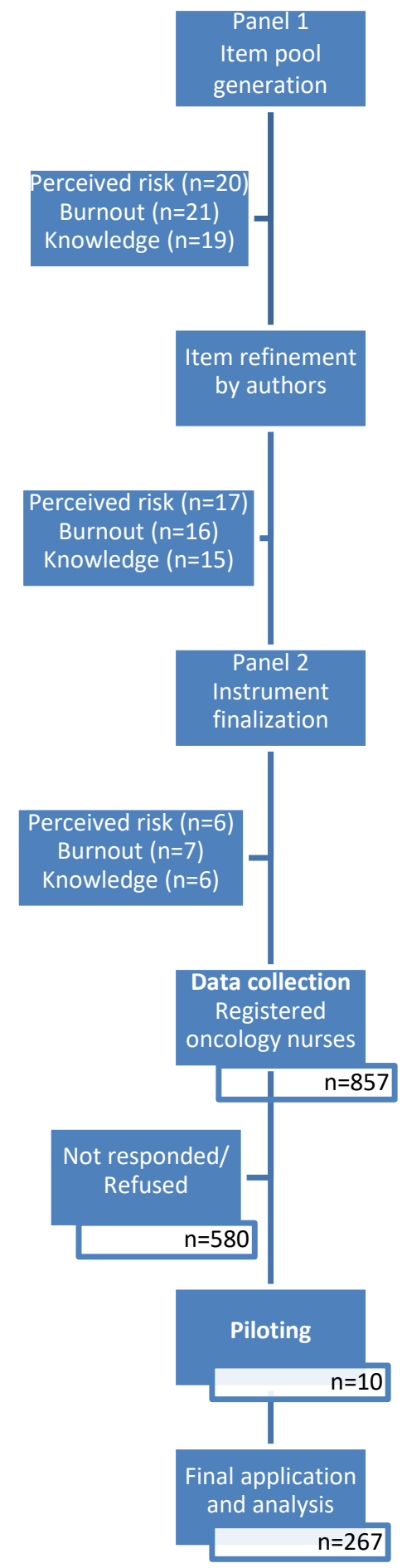

Figure 1. Study flow diagram

\section{Sample size}

There are no general rules for the determination of sample sizes in studies of health measurement instruments. Mokkink et al. recommend larger than 200 respondents and a sample size seven times the number of items [14], while Linacre recommends a minimum sample size of 250 respondents [15]. On the other hand, Hobart et al. suggest a minimum sample size of 80 participants to assess construct validity [16]. Therefore, our sample of 267 participants is considered sufficient.

\section{Sampling and data collection}

The study population consisted of the 857 members registered by the Association of Oncology Nurses. With the help of the nursing association, a data collection tool, composed of 9 demographic questions and 28 study variables, was published at the association's official web site (https://onkohem.org.tr/). The association's management sent individual e-mail invitations to all members. Participant responses were collected anonymously using Google Forms (https://forms.google.com). 


\section{Statistical analysis}

Knowledge questions were scored as 1 for correct and 0 for false answers. Scoring of the scales and knowledge scores was done by summing up the scores of individual items and taking the mean values. Data were presented as n (\%) or mean \pm standard deviation (SD). All analyses were conducted using the SPSS v20.0 software (SPSS Inc., Chicago, IL, USA). The Kolmogorov-Smirnov test was used to test whether numerical variables were normally distributed. The total score of each participant was calculated for each scale. The independent samples t-test was used to compare outcome variables for demographic characteristics. Correlations between numerical variables were evaluated using Pearson's coefficients. A linear regression analysis was conducted to investigate the independent effects of the study variables on burnout scores. Twotailed p-value $<0.05$ was considered statistically significant.

\section{Results}

\section{Participants}

Majority of the participants were married $(64.4 \%, \mathrm{n}=172)$ and women $(87.3 \%, \mathrm{n}=233)$. The mean age was $34.8 \pm 8.4$ years $(\min .20$, max. 58). More than a third $(38.6 \%, \mathrm{n}=103)$ were smokers. Employment of the participants was distributed as $117(43.8 \%)$ at university hospitals, 101 $(37.8 \%)$ at state hospitals, and $49(18.4 \%)$ at private hospitals. Sixty-one $(22.8 \%)$ participants were certified for chemotherapy nursing, while the remaining were general nurses.

\section{Descriptive Findings}

Both risk perception and burnout scores of the participants were above two-thirds of the maximum possible limits, indicating substantial strains. Knowledge scores, on the other hand, were relatively high. There were no significant differences between the certification groups in all three study domains (Table 1).

Table 1. Descriptive findings of the outcome variables

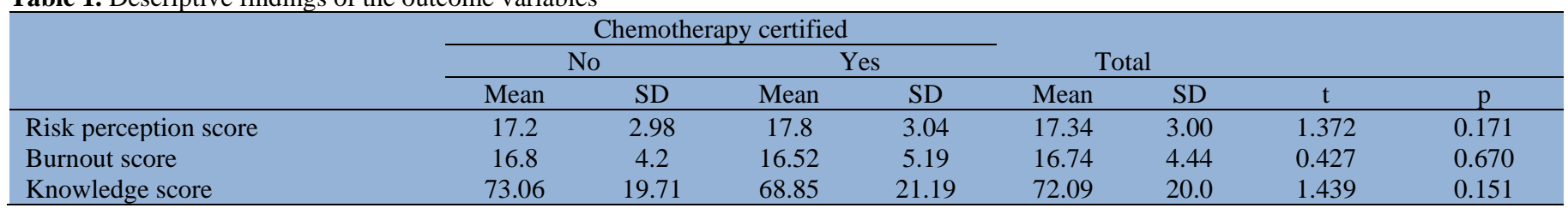

SD: Standard deviation. t: independent samples t-test.

\section{Internal Consistency Reliability, and Construct Validity}

Cronbach's alpha values for the risk perception scale, burnout scale, and knowledge test were $0.539,0.580$, and 0.412 , respectively.

Both the risk perception and burnout scales had adequate Kaiser-Meyer-Olkin sampling adequacy values ( 0.581 and 0.753 , respectively). Bartlett's Test of Sphericity confirmed that our data showed a patterned relationship among the variables (Chi-square; p, 377.503; <0.001 and 269.863; $<0.001$ for the risk perception and burnout scales, respectively). The risk perception scale had a three-factor structure (Table 2), which explained $83.0 \%$ of the total variance, while the burnout scale had a two-factor structure, explaining $50.2 \%$ of the variation (Table 3 ).

Table 2. Mean $( \pm \mathrm{SD})$ item scores and factor structure of the COVID-19 risk perception scale with factor loadings

Compared to other nurses, I have a higher risk of getting COVID-19

If infected, I am concerned to transfer the COVID-19 virus to my cancer patients

If infected, I am concerned to transfer the COVID-19 virus to my family If infected, I am concerned to transfer the COVID-19 virus to my co-workers

Psychologically, I feel safe compared to ICU, chest, and infectious disease department nurses\# Physically, I feel safe compared to nurses at ICU, chest, and infectious disease departments ${ }^{\#}$

*Component 1: Contamination to others, Component 2: Comparative personal risk, Component 3: Personal risk. \#Reverse coded. SD: Standard deviation. *: Range: 0-4.

\begin{tabular}{ccccc} 
& \multicolumn{4}{c}{ Component $^{*}$} \\
Mean* & SD & 1 & 2 & 3 \\
\hline 2.39 & 1.17 & & & 0.997 \\
3.48 & 0.71 & 0.742 & & \\
3.64 & 0.66 & 0.882 & & \\
3.57 & 0.60 & 0.903 & & \\
2.19 & 1.21 & & 0.955 & \\
2.06 & 1.24 & & 0.956 & \\
\hline
\end{tabular}

Table 3. Mean $( \pm \mathrm{SD})$ item scores and factor structure of the COVID-19 burnout scale with factor loadings

\begin{tabular}{lccc} 
& & \multicolumn{2}{c}{ Component } \\
Since the COVID-19 pandemic; & Mean* & SD & 1 \\
\hline I don't have motivation to exercise & 2.67 & 1.17 & 0.470 \\
I have less time for cultural activities & 2.26 & 1.23 & 0.691 \\
I spend more time following news on social media & 2.53 & 1.15 & 0.720 \\
I have a need for psychological counseling & 1.83 & 1.22 & 0.752 \\
I feel I am exhausted than ever before & 2.55 & 1.17 & 0.793 \\
I have much more work to do & 2.48 & 1.21 & 0.770 \\
I have less time for myself & 2.42 & 1.18 & 0.628 \\
\hline
\end{tabular}

Component 1: Social and psychological burnout, Component 2: Work-related burnout. SD: Standard deviation. *: Range: 0-4. 


\section{Outcomes}

COVID-19 knowledge scores showed a significant positive correlation with burnout scores $(\mathrm{r}=0.499, \mathrm{p}<0.001)$ but a negative correlation with age $(r=-0.153, p=0.013)$. There was no significant correlation between burnout scores and risk perception or risk perception and age $(p>0.05)$. A linear regression analysis was conducted to investigate the independent effects of COVID-19 knowledge score, COVID-19 risk perception score, age (years), sex, and having chemotherapy nurse certification on burnout scores. It was determined that after adjusting for the possible confounders, the COVID-19 knowledge score was the only significant variable independently affecting burnout scores (Table 4).

Table 4. Linear regression analysis computer output

\begin{tabular}{|c|c|c|c|c|c|c|}
\hline & \multicolumn{2}{|c|}{ Unstandardized Coefficients } & \multirow[b]{2}{*}{$\mathrm{t}$} & \multirow[b]{2}{*}{$\mathrm{p}$} & \multicolumn{2}{|c|}{$95.0 \% \mathrm{CI}$ for $\mathrm{B}$} \\
\hline & B & SE & & & Lower & Upper \\
\hline$\overline{\text { (Constant) }}$ & 8.107 & 1.985 & 4.083 & $<0.001$ & 4.197 & 12.016 \\
\hline COVID-19 knowledge score & 0.109 & 0.012 & 9.101 & $<0.001$ & 0.086 & 0.133 \\
\hline COVID-19 risk perception score & 0.080 & 0.080 & 1.009 & 0.314 & -0.077 & 0.237 \\
\hline Age (years) & -0.018 & 0.030 & -0.607 & 0.544 & -0.077 & 0.041 \\
\hline Male sex ${ }^{*}$ & -0.538 & 0.738 & -0.729 & 0.467 & -1.992 & 0.916 \\
\hline Certified chemotherapy nurse ${ }^{*}$ & 0.246 & 0.588 & 0.419 & 0.676 & -0.912 & 1.404 \\
\hline
\end{tabular}

Dependent Variable: Burnout score, SE: Standard error, CI: Confidence interval, *Dummy variable

\section{Discussion}

\section{Key Results}

This study demonstrated relatively high COVID-19 risk perception and burnout scores of chemotherapy nurses. The participants' mean COVID19 knowledge scores were $72 \%$. After adjusting for possible confounders, COVID-19 knowledge score was the only significant variable independently affecting burnout scores.

\section{Interpretation}

Health professionals are under numerous work stressors not only because of their workload, but also because of the chemical and biological risks associated with the occupation [17]. Especially the hospital setting is associated with higher psychosocial tension [18]. Burnout is a physical, emotional, and mental exhaustion syndrome manifested by emotional exhaustion, changes in work-related attitudes and behaviors, and decreased sense of accomplishment, as well as physical tiredness, chronic fatigue, feelings of helplessness and hopelessness together with the development of a negative self-concept [19-21]. On the other hand, according to Pines and Aronson [22], burnout is a loss of enthusiasm, energy, idealism, perspective, and purpose, and is a physical, emotional, and mental state of exhaustion that causes constant stress, despair, helplessness, and a trapped feeling. The condition is accepted as an occupational disease in some European countries [23].

Burnout is a common entity encountered among nursing staff. A prevalence of about 30\% was reported in emergency nurses [24]. Oncology nurses are another group considerably affected by emotional exhaustion and low levels of personal accomplishment. The presence and the risk of burnout among these staff members are considerable too [18]. Considering that oncology nurses are dealing mostly with poor-prognosis patients, relatively high burnout scores in our study are not surprising.

Radiation and contact with infectious diseases are some examples of the potential hazards exposed. With the emergence of the COVID-19 pandemic, health professionals are under much greater danger than before. SARS-CoV-2 infection among health workers is four times the number of previous cases per year. On the other hand, the majority of incidents (around 60\%) are seen in nurses [25]. The close working environment in the oncology department disables the health providers keeping physical distance to the patients. Furthermore, the increased anxiety of the patients may have been reflected to the caring nurses, which are factors explaining the increased risk and burnout in this profession.

Spreading of the COVID-19 infection among chemotherapy nurses is a medal with two sides. On one side are the nurses, but possibly more vulnerable are patients with their weakened immunities [26]. Infected nurses can rapidly spread the virus to their patients causing non-compensable deterioration in patient outcomes, which may be an additive factor increasing risk perception and stress among the nurses.

This study confirmed that higher knowledge is associated with higher risk perception. It is recognized that beliefs, knowledge, values, and attitudes affect decisions as well as behaviors, changing the way people react to environmental pressures [27]. Therefore, it is essential to understand the risk perception of the health personnel to improve communication, build trust, and establish collaborating governance. However, beyond the level of knowledge, there are other factors such as familiarity, controllability, and the immediacy of danger, affecting risk perception [28], which were not addressed in this study.

Many institutions, such as the European Society for Medical Oncology, American Society of Clinical Oncology, and National Comprehensive Cancer Network, have developed guidelines to combat the worldwide destructive effects of the COVID-19 pandemic [29-31]. Considering the high knowledge scores in our study, it may be suggested that the population of interest is actively following recent guidelines and literature on the COVID-19 pandemic.

The COVID-19 pandemic is potentially the biggest public health crisis since the 1918 flu epidemic. This crisis has put unprecedented difficulties in managing those affected, placing enormous and overwhelming stress on health systems and healthcare professionals. During such situations, timely evidence for treatment options is critical [32]. Not expecting that the COVID-19 crisis will be solved in due time, we suggest taking actions to protect the physical and mental well-being of the nursing staff, as depicted by this study. 


\section{Limitations}

A substantial limitation of this study is that it did not compare the burnout outcomes with the well-known and validated Maslach Burnout Inventory. Our findings should be confirmed based on available external criteria. Hence, we cannot claim the concurrent validity of the study instrument. Further, data collection was based on an online survey, which carries its advantages and limitations.

\section{Conclusion}

Chemotherapy nurses are under significant strain concerning the new outbreak. A significant positive correlation was found between the level of COVID-19 knowledge and personal risk perception of the chemotherapy nurses, while there was a negative correlation between COVID-19 knowledge and burnout scores. Increasing the knowledge of the nurses by in-service training could raise their awareness and risk perception, leading to further adherence to the preventive measures. On the other hand, to keep the health system working, the struggle against the COVID19 must include precautions to prevent work-related exhaustion and support nurses experiencing burnout.

\section{Acknowledgments}

We would like to thank Figen Bay, the chairman of the Oncology Nurses Association, and Assoc. Prof Dr Ozgur Tanriverdi from Mugla Sitki Kocman University, Department of Medical Oncology, for their support.

\section{Conflict of interest: None}

Financial support: None

\begin{tabular}{|r|r|l|}
\hline \multicolumn{2}{|c|}{ Author Contributions } & Author Initials \\
\hline SCD & Study Conception and Design & LK \\
\hline AD & Acquisition of Data & LK \\
\hline AID & Analysis and Interpretation of Data & LK \\
\hline DM & Drafting of Manuscript & LK \\
\hline CR & Critical Revision & LK \\
\hline
\end{tabular}

\section{Prior publication: None}

\section{References}

1. Castagnoli R, Votto M, Licari A, Brambilla I, Bruno R, Perlini S et al. Severe Acute Respiratory Syndrome Coronavirus 2 (SARS-CoV-2) Infection in children and adolescents: a systematic review. JAMA Pediatr 2020;174(9):882-9. http://doi.org/10.1001/jamapediatrics.2020.1467

2. Turkey confirms first coronavirus patient, recently returned from Europe. Daily Sabah 2020. https://www.dailysabah.com/turkey/turkeyremains-firm-calm-as-first-coronavirus-case-confirmed/news (Accessed October 26, 2020)

3. Lotfinejad N, Peters A, Pittet D. Hand hygiene and the novel coronavirus pandemic: the role of healthcare workers. J Hosp Infect 2020;105(4):776-7. https://doi.org/10.1016/j.jhin.2020.03.017

4. Shanafelt T, Ripp J, Trockel M. Understanding and addressing sources of anxiety among health care professionals during the COVID-19 pandemic. JAMA 2020;323(21):2133-4. https://doi.org/10.1001/jama.2020.5893

5. Hall LM, Angus J, Peter E, O'Brien-Pallas L, Wynn F, Donner G. Media portrayal of nurses' perspectives and concerns in the SARS crisis in Toronto. J Nurs Scholarsh 2003;35(3):211-6. https://doi.org/10.1111/j.1547-5069.2003.00211.x

6. Zakeri R, Bendayan R, Ashworth M, Bean DM, Dodhia H, Durbaba S et al. A case-control and cohort study to determine the relationship between ethnic background and severe COVID-19. E Clin Med 2020;28:100574. https://doi.org/10.1016/j.eclinm.2020.100574

7. Huang L, Lin G, Tang L, Yu L, Zhou Z. Special attention to nurses' protection during the COVID-19 epidemic Critical Care 2020;24(120). https://ccforum.biomedcentral.com/articles/10.1186/s13054-020-2841-7 (Accessed October 26, 2020)

8. Freudenberger HJ. Staff burnout. J Soc Issues 1974;30(1):159-65. https://doi.org/10.1111/j.1540-4560.1974.tb00706.x

9. Aiken LH, Cimiotti JP, Sloane DM, Smith HL, Flynn L, Neff DF. Effects of nurse staffing and nurse education on patient deaths in hospitals with different nurse work environments. J Nurs Adm 2012;42(12):1047-53. https://doi.org/10.1097/MLR.0b013e3182330b6e

10. Geuens N, Verheyen H, Vlerick P, Van Bogaert P, Franck E. Exploring the influence of core-self evaluations, situational factors, and coping on nurse burnout: a cross-sectional survey study. PLoS One 2020;15(4):e0230883. https://doi.org/10.1371/journal.pone.0230883

11. Neocleous M. "Don't Be Scared, Be Prepared" Trauma-Anxiety-Resilience. Alternatives 2012;37:188-98. https://www.jstor.org/stable/23412507 (Accessed October 26, 2020)

12. Henry BJ. Nursing burnout interventions: what is being done? Clin J Oncol Nurs 2014;18(2):211-4. https://doi.org/10.1188/14.CJON.211$\underline{214}$

13. Mokkink LB, Terwee CB, Knol DL, Stratford PW, Alonso J, Patrick DL et al. The COSMIN checklist for evaluating the methodological quality of studies on measurement properties: a clarification of its content. BMC Med Res Methodol 2010;10:22. https://doi.org/10.1186/1471-2288-10-22

14. Mokkink LB, Prinsen C, Patrick DL, Alonso J, Bouter LM, de Vet HC et al. COSMIN methodology for systematic reviews of patient-reported outcome measures (PROMs). User Man 2018;78:1. https://www.cosmin.n1/wp-content/uploads/COSMIN-syst-review-for-PROMsmanual_version-1_feb-2018.pdf (Accessed October 26, 2020)

15. Linacre JM. Sample size and item calibration (or person measure) stability. Rasch Measurement Transactions 1994;7(4):328 https://www.rasch.org/rmt/rmt74m.htm (Accessed October 26, 2020)

16. Hobart JC, Cano SJ, Warner TT, Thompson AJ. What sample sizes for reliability and validity studies in neurology? J Neurol 2012;259:268194. https://doi.org/10.1007/s00415-012-6570-y

17. Aronsson G, Theorell T, Grape T, Hammarström A, Hogstedt C, Marteinsdottir I et al. A systematic review including meta-analysis of work environment and burnout symptoms. BMC Public Health 2017;17:264. https://doi.org/10.1186/s12889-017-4153-7 
18. Cañadas-De la Fuente GA, Gómez-Urquiza JL, Ortega-Campos EM, Cañadas GR, Albendín-García L, De la Fuente-Solana EI. Prevalence of burnout syndrome in oncology nursing: A meta-analytic study. Psychooncology 2018;27(5):1426-33. https://doi.org/10.1002/pon.4632

19. Maslach C. Job burnout: How people cope. Public Welf 1978;36:56-8. https://www.ncjrs.gov/App/Publications/abstract.aspx?ID=68886 (Accessed October 26, 2020)

20. Capri B. [Turkish adaptation of the burnout measure: a reliability and validity study] (in Turkish). Mersin Univ J Fac Edu 2006;2(1):62-77. https://dergipark.org.tr/tr/download/article-file/161006 (Accessed October 26, 2020)

21. Maslach C, Jackson SE. The measurement of experienced burnout. J Organ Behav 1981;2(2):99-113. https://doi.org/10.1002/job.4030020205

22. Pines A, Aronson E. Career burnout: Causes and cures. Free press; 1988. https://www.scirp.org/(S(vtj3fa45qm1ean45vvffcz55))/reference/ReferencesPapers.aspx?ReferenceID=1640084 (Accessed October 26, 2020)

23. Schaufeli WB, Leiter MP, Maslach C. Burnout: 35 years of research and practice. Career Dev Int 2009;14(3):204-20. https://www.wilmarschaufeli.nl/publications/Schaufeli/311.pdf (Accessed October 26, 2020)

24. Gómez-Urquiza JL, De la Fuente-Solana EI, Albendín-García L, Vargas-Pecino C, Ortega-Campos EM, Cañadas-De la Fuente GA. Prevalence of burnout syndrome in emergency nurses: A Meta-Analysis. Crit Care Nurse 2017;37(5):e1-9. https://doi.org/10.4037/ccn2017508

25. Nienhaus A, Hod R. COVID-19 among health workers in Germany and Malaysia. Int J Environ Res Public Health 2020;17(13):4881. https://doi.org/10.3390/ijerph17134881

26. Burki TK. Cancer care in the time of COVID-19. Lancet Oncol 2020;21:628. https://doi.org/10.1016/S1470-2045(20)30201-1

27. Cori L, Bianchi F, Cadum E, Anthonj C. Risk perception and COVID-19. Int J Environ Res Public Health 2020;17(9):3114. https://doi.org/10.3390/ijerph17093114

28. Simoncini M. Risk and communication. Theories, models, problems, Cambridge University Press, 2018. https://doi.org/10.1017/CBO9780511814679

29. Series CW. Coronavirus Disease 2019 (COVID-19) Resources for the cancer care community. Natl Compr Cancer Netw 2020. https://www.nccn.org/covid-19/ (Accessed October 26, 2020).

30. ASCO coronavirus resources. Am Soc Clin Oncol 2020. https://www.asco.org/asco-coronavirus-information (Accessed October 26, 2020)

31. ESMO. COVID-19 and cancer. Eur Soc Med Oncol 2020. https://www.esmo.org/covid-19-and-cancer (Accessed October 26, 2020)

32. Gosain R, Abdou Y, Singh A, Rana N, Puzanov I, Ernstoff MS. COVID-19 and cancer: a comprehensive review. Curr Oncol Rep 2020;22:53. https://doi.org/10.1007/s11912-020-00934-7 